\title{
Pengaruh Penempatan dan Beban Kerja Terhadap Motivasi Kerja Pegawai pada Kantor Dinas Pengairan Provinsi Aceh
}

\author{
Saiful AMRI * \\ Fakultas Ekonomi, Universitas Serambi Mekkah, \\ Jalan Batoh, Lueng Bata, Kota Banda Aceh, Provinsi Aceh, Indonesia \\ saifulamri@serambimekkah.ac.id
}

\section{Article's history:}

Received 24 August 2019; Received in revised form 2 February 2020; Accepted 11 February, 2020; Published 30 February 2020. All rights reserved to the Lembaga Otonom Lembaga Informasi dan Riset Indonesia (KITA INFO dan RISET).

\section{Suggested citation:}

Amri, S., 2020. Pengaruh Penempatan dan Beban Kerja Terhadap Motivasi Kerja Pegawai pada Kantor Dinas Pengairan Provinsi Aceh. JEMSI (Jurnal Ekonomi, Manajemen, dan Akuntansi), Volume 6 (1): 23-31. DOI: https://doi.org/10.35870/jemsi.v6i1.335.

\section{ABSTRAK:}

Penelitian ini bertujuan untuk mengetahui pengaruh penempatan dan beban kerja terhadap motivasi kerja pegawai pada Kantor Dinas Pengairan Provinsi Aceh. Populasi penelitian ini berjumlah 404 orang pegawai, dan teknik penarikan sampel menggunakan teknik slovin sehingga diperoleh 44 orang pegawai sebagai sampel. Model yang digunakan dalam penelitian ini adalah analisis regresi linier berganda. Hasil penelitian menunjukkan bahwa penempatan dan beban kerja berpengaruh signifikan terhadap motivasi kerja pegawai pada Kantor Dinas Pengairan Provinsi Aceh, hal ini dibuktikan bahwa penempatan dan beban kerja merupakan faktor yang mempengaruhi motivasi kerja pegawai sebesar 60,6 dan sisanya sebesar $39,4 \%$ dijelaskan oleh variabel lain diluar dari pada penelitian ini, misalnya penghargaa, kompensasi, budaya organisasi, disiplin kerja dan lain-lain. Nilai koefesien korelasi (R) menunjukkan bahwa derajat hubungan (korelasi) antara penempatan dan beban kerja dengan motivasi kerja sebesar $77,8 \%$, artinya motivasi kerja pegawai pada Kantor Dinas Pengairan Provinsi Aceh mempunyai hubungan cukup erat dan positif dengan penempatan dan beban kerja. Hasil pengujian statistik menunjukkan bahwa penempatan dan beban kerja secara simultan berpengaruh signifikan terhadap motivasi kerja pegawai pada Kantor Dinas Pengairan Provinsi Aceh, dengan nilai Fhitung $>$ Ftabel $(31,475>3,226)$. Sedangkan secara parsial penempatan dan beban kerja berpengaruh signifikan terhadap motivasi kerja pegawai pada Kantor Dinas Pengairan Provinsi Aceh, dengan nilai thitung>ttabel $(4,756$ dan 2,109>2,017). Berdasarkan hasil analisis regresi linier berganda dapat diketahui bahwa dari kedua variabel yang diteliti, ternyata variabel penempatan (X1) mempunyai pengaruh paling dominan terhadap motivasi kerja pegawai pada Kantor Dinas Pengairan Provinsi Aceh, dengan nilai koefisien sebesar 0,590, kemudian diikuti oleh variabel beban kerja (X2) dengan nilai koefisien sebesar 0,262.

Kata Kunci: Penempatan; Beban Kerja; Motivasi Kerja.

JEL Classification: M52; J54.

\section{PENDAHULUAN}

Dalam era kompetisi sekarang ini, setiap instansi harus mampu mengembangkan dan meningkatkan penempatan dan beban kerja dengan mengadakan berbagai cara yang tersusun dalam program untuk meningkatkan motivasi kerja para pegawai. Banyak faktor yang terkait dalam perbaikan motivasi kerja pegawai. Salah satu faktor penting yang harus diperhatikan oleh Dinas Pengairan Provinsi Aceh dalam mencapai tujuannya adalah faktor sumber daya manusia (SDM). Manusia sebagai penggerak perusahaan merupakan faktor utama karena eksistensi instansi tergantung pada manusia-manusia yang terlibat dibelakangnya. Untuk dapat mencapai tujuan dari perusahaan diperlukan sumber daya manusia yang kompeten dalam melaksanakan tugasnya.

Pengelolaan terhadap sumber daya manusia merupakan hal yang penting dalam pencapaian tujuan. Umumnya pimpinan instansi mengharapkan motivasi kerja pegawai dalam mengerjakan tugas-tugas yang diberikan oleh instansi dapat diselesaikan dengan baik. Dinas Pengairan Provinsi Aceh menyadari bahwa sumber daya manusia merupakan modal dasar dalam mencapai suatu tujuan instansi, oleh karena itu kualitas sumber daya manusia senantiasa harus dikembangkan dan diarahkan agar tercapainya tujuan yang telah ditetapkan oleh 
suatu instansi atau organisasi. Motivasi kerja pegawawi dalam suatu instansi dapat dianggap sederhana dan dapat pula menjadi masalah yang kompleks, karena pada dasarnya manusia mudah untuk dimotivasi dengan memberikan apa yang menjadi keinginannya. Menurut Luthans (2006:25) motivasi adalah proses sebagai langkah awal seseorang melakukan tindakan akibat kekurangan secara fisik dan psikis atau dengan kata lain adalah suatu dorongan yang ditunjukan untuk memenuhi tujuan tertentu. Apabila kondisi ini tidak terjadi, maka akan menurunkan motivasi kerja pegawai dan akan berdampak pada kinerja pegawai yang menurun.

Menentukan suatu pekerjaan dapat dikerjakan atau diselesaikan dengan baik dapat dilihat dari pemberian motivasi kerja yang jelas. Semakin jelas pemberian motivasi kerja maka dalam pelaksanaan pekerjaan semakin mudah dan dapat dikerjakan secara efektif dan efisien. Motivasi kerja memberikan ketegasan dan standar tugas yang harus dicapai oleh setiap pegawai, dimana apabila pemberian motivasi kerja kurang jelas maka akan mengakibatkan para pegawai kurang memahami tugas dan tanggung jawabnya, yang akan mengakibatkan pekerjaan tidak dapat terselesaikan dengan baik.

Motivasi memiliki peranan yang sangat penting dalam setiap aktifitas tiap pegawai. Motivasi yang ada pada seseorang merupakan kekuatan pendorong yang

mewujudkan suatu perilaku guna mencapai tujuan kepuasan dirinya. Seringkaliorang berpendapat bahwa motivasi kerja dapat ditimbulkan apabila mendapatkanimbalan yang baik, dan adil, namun kenyataan meskipun sudah diberi imbalanyang baik tetapi pekerjaannya belum maksimal. Setiap manusia tentu mempunyai dasar alasan mengapa seseorang bersedia melakukan jenis kegiatan atau pekerjaan tertentu, mengapa orang yang satu bekerja dengan giat, sedangkan yang lain biasa saja. Semua ini ada dasar dan alannya yang mendorong seseorang bekerja seperti itu, atau dengan kata lain pasti ada motivasinya. Motivasi kerja pegawai dapat dipengaruhi oleh penempatan dan beban kerja.

Penempatan pegawai yang kurang tepat dapat berakibat terhambatnya motivasi kerja pegawai yang memiliki produktivitas kerja dan kepuasan kerja tinggi sehingga pegawai cenderung untuk berhenti pada bulanbulan pertama bekerja (Rivai, 2011:187). Penempatan kerja pegawai yang baik dilakukan instansi dilihat dari pengalaman kerja pegawai, pengalaman kerja merupakan kunci pembuka untuk menciptakan motivasi kerja pegawai yang baik bagi instansi dengan adanya pengalaman kerja dapat menempatkan pegawai sesuai dengan persyaratan jabatan sehingga dapat bekerja dengan baik dan berprestasi.

Beban kerja adalah aktivitas satuan organisasi atau beban kerja masing-masing pejabat atau pegawai hendaknya merata sehingga dapat dihindarkan adanya satuan organisasi yang terlalu banyak aktivitasnya dan ada satuan organisasi terlalu sedikit aktivitasnya demikian pula dapat dihindarkan adanya pejabat atau pegawai yang terlalu bertumpuk-tumpuk tugasnya dan ada pejabat atau pegawai yang sedikit beban kerjanya sehingga nampak terlalu banyak menganggur (Sutarto, 2006:122). Beban kerja yang terlalu sedikit dapat menyebabkan kurang adanya rangsangan akan mengarah kesemangat dan motivasi yang rendah untuk kerja, karena pegawai akan merasa bahwa dia tidak maju maju dan merasa tidak berdaya untuk memperlihatkan bakat dan keterampilannya.

Penempatan kerja memiliki hubungan langsung dengan motivasi kerja pegawai. Sedangkan beban kerja memiliki hubungan yang langsung dengan motivasi kerja. Kedua faktor tersebut keberadaannya akan mempengaruhi motivasi kerja. Karena kedudukan dan hubunganya itu, maka sangatlah strategis untuk meningkatkan motivasi kerja pegawai dimulai dari penempatan kerja dan beban kerja. Dalam meningkatkan penempatan dan beban kerja tidak hanya cukup pada memotivasi pegawai tapi juga didasari oleh seorang pemimpin yang dapat memotivasi dan mengarahkan pegawai. Perlunya mengetahui motivasi merupakan salah satu alasan penting meskipun penelitian tentang motivasi yang dilakukan manusia relatif terlambat. Ketidakingintahuan tentang motivasi menggejala sehingga penelitian tersebut tidak perlu dilaksanakan dan menunjukkan nilai kebenaran yang jelas. Bahkan, seringkali hasilnya terlihat mengagumkan, atau diabaikan apabila dianggap tidak praktis untuk diterapkan atau dipresentasikan.

\section{TINJAUAN KEPUSTAKAAN}

\section{Penempatan}

Menurut Mathis \& Jackson (2009:262) menyatakan bahwa penempatan adalah menempatkan posisi seseeorang ke posisi pekerjaan yang tepat, seberapa baik seorang pegawai cocok dengan pekerjaanya akan mempengaruhi jumlah dan kualitas pekerjaan. Menurut Sulistiyani \& Rosidah (2008:151) penempatan adalah suatu kebijakan yang diambil oleh pimpinan suatu instansi, atau bagian personalia untuk menentukan seorang pegawai masih tetap atau tidak ditempatkan pada suatu posisi atau jabatan tertentu berdasarkan pertimbangan keahlian, keterampilan atau kualifikasi tertentu. 
Menurut Hasibuan (2010:152) penempatan (placement) pegawai adalah tindak lanjut dari seleksi yaitu menempatkan calon karyawan yang diterima (lulus seleksi) pada jabatan/pekerjaan yang membutuhkannya dan sekaligus mendelegasikan authority kepada orang tersebut, dengan demikian calon pegawai itu akan dapat mengerjakan tugas-tugasnya dijabatan bersangkutan. Menurut Hariandja (2007:156) penempatan merupakan proses penugasan atau pengisian jabatan atau penugasan kembali pegawai pada tugas atau jabatan baru atau jabatan yang berbeda.

Menurut Rivai (2011:211) mengemukakan bahwa pengertian penempatan adalah penugasan atau penugasan kembali seorang pegawai pada pekerjaan barunya. Menurut Siswanto (2007:162) penempatan adalah proses pemberian tugas dan pekerjaan kepada tenaga kerja yang lulus seleksi untuk dilaksanakan sesuai ruang lingkup yang telah ditetapkan, serta mampu mempertanggungjawabkan segala risiko dan kemungkinankemungkinan yang terjadi atas tugas dan pekerjaan, wewenang, serta tanggung jawabnya. Menurut Sedarmayanti (2011:120) mengatakan bahwa Penempatan adalah penugasan kembali pegawai pada pekerjaan atau jabatan baru. Sedangkan Faustino (2008:117) mengungkapkan bahwa penempatan pegawai merupakan salah satu fungsi terpenting dalam manajemen sumber daya manusia, tepat tidaknya seseorang ditempatkan pada suatu posisi tertentu tergantung pada fungsi penempatan ini. Jika fungsi ini tidak dilaksanakan dengan baik maka dengan sendirinya akan berakibat fatal terhadap pencapaian tujuan-tujuan organisasi.

\section{Beban Kerja}

Beban kerja merupakan salah satu aspek yang harus di perhatikan oleh setiap perusahaan, karena beban kerja salah satu yang dapat meningkatkan motivasi kerja pegawai. Beban kerja adalah frekuensi kegiatan rata-rata dari masing-masing pekerjaan dalam jangka waktu tertentu (Irwandy, 2007:23). Menurut Menpan (Dhini Rama Dhania, 2010:16) beban kerja adalah sekumpulan atau sejumlah kegiatan yang harus diselesaikan oleh suatu unit organisasi atau pemegang jabatan dalam jangka waktu tertentu. Menurut Hart \& Staveland dalam Tarwaka (2011:106) beban kerja merupakan suatu yang muncul dari interaksi antara tuntutan tugas-tugas lingkungan kerja dimana digunakan sebagai tempat kerja, keterampilan dan persepsi dari pekerja. Menurut Hasibuan (2010:116) analisis beban kerja adalah penentuan jumlah pekerja yang diperlukan untuk menyelesaikan suatu pekerjaan dalam jangka waktu tertentu.

Beban kerja adalah keadaan dimana pekerja dihadapkan pada tugas yang harus diselesaikan dalam batas waktu tertentu (Supardi, 2007:46). Menurut Simamora (2008:56) beban kerja adalah mengidentifikasi baik jumlah karyawan maupun kualifikasi pegawai yang diperlukan untuk mencapai tujuan organisasi. Menurut Sugiyanto (2009:14) beban kerja adalah semua faktor yang menentukan orang yang sedang bekerja. Menurut Munandar (2008:383) beban kerja adalah suatu kondisi dari pekerjaan dengan uraian tugasnya yang harus diselesaikan pada batas waktu tertentu. Menurut Sutarto (2006:122) beban kerja adalah aktivitas satuan organisasi atau beban kerja masing-masing pejabat atau pegawai hendaknya merata sehingga dapat dihindarkan adanya satuan organisasi yang terlalu banyak aktivitasnya dan ada satuan organisasi terlalu sedikit aktivitasnya demikian pula dapat dihindarkan adanya pejabat atau pegawai yang terlalu bertumpuk-tumpuk tugasnya dan ada pejabat atau pegawai yang sedikit beban kerjanya sehingga nampak terlalu banyak menganggur.

\section{Motivasi Kerja}

Menurut Wagner dan Hollenbeck (2009:81), seseorang yang termotivasi untuk bekerja akan terus ingin belajar mengetahui hal-hal baru untuk meningkatkan performa kerjanya. Menurut Munandar (2008:323) motivasi kerja adalah suatu proses dimana kebutuhan-kebutuhan mendorong seseorang untuk melakukan serangkaian kegiatan yang mengarah ke tercapainya tujuan tertentu. Tujuan yang jika berhasil dicapai, akan memuaskan atau memenuhi kebutuhan-kebutuhan tersebut. Menurut Winardi (2011:40) motivasi berkaitan dengan kebutuhan. Kita sebagai manusia selalu mempunyai kebutuhan yang diupayakan untuk dipenuhi. Untuk mencapai keadaan termotivasi, maka kita harus mempunyai tindakan tertentu yang harus dipenuhi, dan apabila kebutuhan itu terpenuhi, maka muncul lagi kebutuhan-kebutuhan yang lain hingga semua orang termotivasi. Menurut Nawawi (2007:351) menyatakan bahwa motivasi berarti suatu kondisi yang mendorong atau menjadi sebab seseorang melakukan sesuatu perbuatan (kegiatan).

Menurut Hasibuan (2010:143) motivasi adalah pemberian daya penggerak yang menciptakan kegairahan kerja seseorang agar mereka mau bekerja sama, bekerja efektif dan terintegrasi dengan segala daya upayanya untuk mencapai kepuasan. Menurut Mathis dan Jackson (2009:114) motivasi adalah keinginan dalam diri seseorang yang menyebabkan orang tersebut bertindak. Menurut maslow dalam Robbins (2009:166) mengemukakan bahwa motivasi adalah suatu proses pemenuhan kebutuhan. Menurut George dan Jones (2009:175) pemberian motivasi kerja adalah suatu kebutuhan psikologis didalam diri seseorang yang menentukan 
arah perilaku seseorang didalam organisasi yang menyebabkan pergerakan, arahan, usaha, dan kegigihan dalam menghadapi rintangan untuk mencapai suatu tujuan. Sedangkan menurut Mangkunegara (2009:93) motivasi adalah kondisi yang menggerakan pegawai agar mampu mencapai tujuan dari motifnya.

\section{Kerangka Pemikiran}

Kerangka pemikiran merupakan model konseptual tentang bagaimana landasan teori yang telah dijabarkan berhubungan secara logis dengan berbagai faktor yang diidentifikasi sebagai masalah yang penting (Sekaran, 2006:12). Sebuah model yang baik dapat menjelaskan hubungan antar variabel penelitian, yakni variabel independen dan variabel dependen (Ferdinand, 2006:54). Berdasarkan tujuan penelitian, landasan teoritis, dan hasil penelitian sebelumnya yang sudah dijelaskan di atas, maka dalam penelitian ini motivasi kerja dipengaruhi oleh penempatan dan beban kerja. Karena itu kerangka pemikiran dalam penelitian ini dapat dilihat pada Gambar 1.

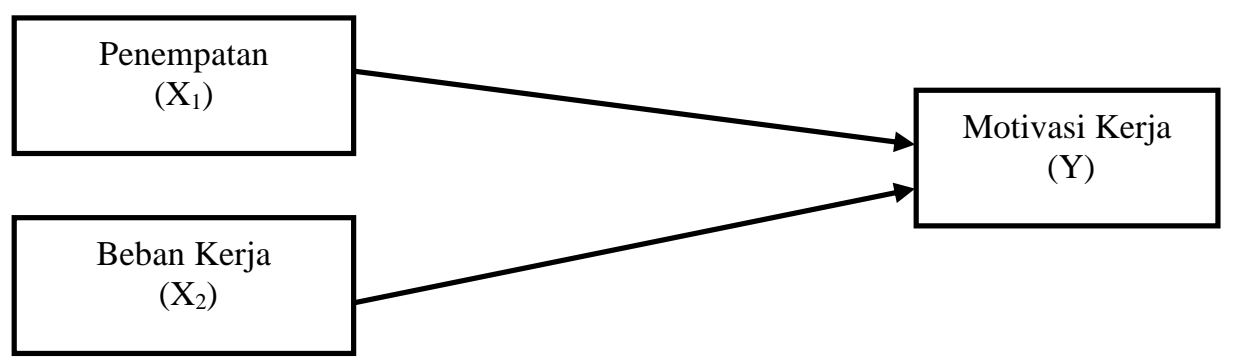

Gambar 1. Kerangka Pemikiran

\section{Hipotesis Penelitian}

Hipotesis merupakan jawaban sementara yang di susun oleh peneliti, yang kemudian akan diuji kebenarannya melalui penelitian yang di lakukan (Kuncoro, 2009:59). Berdasarkan kerangka konseptual diatas maka hipotesis dalam penelitian ini adalah:

$\mathrm{H}_{\mathrm{a} 1} \quad$ : Diduga penempatan dan beban kerja berpengaruh secara simultan terhadap motivasi kerja pada Kantor Dinas Pengairan Provinsi Aceh

$\mathrm{H}_{\mathrm{a} 2} \quad$ : Diduga penempatan berpengaruh secara parsial terhadap motivasi kerja pada Kantor Dinas Pengairan Provinsi Aceh

$\mathrm{H}_{\mathrm{a} 3} \quad$ : Diduga beban kerja berpengaruh secara parsial terhadap motivasi kerja pada Kantor Dinas Pengairan Provinsi Aceh

\section{METODE PENELITIAN}

Menurut Arikunto (2011:173) berpendapat bahwa populasi adalah keseluruhan subyek penelitian. Sedangkan sampel atau contoh adalah sebagian atau wakil populasi yang diteliti (Arikunto, 2011:174). Pengambilan sampel ini harus dilakukan sedemikian rupa sehingga diperoleh sampel yang benar-benar dapat berfungsi atau dapat menggambarkan keadaan populasi yang sebenarnya. Dengan istilah lain, sampel harus representatif. Menurut Arikunto (2011:112) apabila subyeknya kurang dari 100 orang, lebih baik diambil semua sehingga penelitiannya merupakan penelitian populasi. Selanjutnya jika jumlah subyeknya besar dapat diambil antara 10\%-15\% atau 20\%-25\%. Populasi penelitian ini adalah seluruh pegawai pada Kantor Dinas Pengairan Provinsi Aceh yang berjumlah 404 orang. Menurut Husein Umar (2011:78) Penentuan jumlah sampel menggunakan rumus slovin yaitu sebagai berikut:

Dimana :

$$
n=\frac{N}{1+N e^{2}}
$$

\footnotetext{
n : Ukuran sampel

N : : Ukuran Populasi

e : Prosentase kelonggaran ketelitian karena kesalahan pengambilan sampel.
} 
Dengan menggunakan rumus tersebut diatas, maka ukuran sampel dapat dilihat sebagai berikut:

$$
\begin{aligned}
n & =\frac{404}{1+404(0,15)^{2}} \\
n & =\frac{404}{1+404(0,0225)} \\
n & =\frac{404}{9,1125} \\
n & =44,33 \text { dibulatkan menjadi } 44 \text { orang }
\end{aligned}
$$

\section{Data dan Teknik Pengumpulan Data}

\section{Wawancara}

Metode pengumpulan data yang digunakan dalam penelitian ini adalah sebagai berikut:

Wawancara adalah proses tanya jawab dalam penelitian yang berlangsung secara lisan dimana dua orang atau lebih bertatap muka, mendengarkan secara langsung informasi-informasi atau keterangan-keterangan. Penulis mewawancari kepala bagian di Dinas Pengairan Provinsi Aceh untuk mengetahui produktivitas pegawai.

2. Angket

Angket merupakan sejumlah pertanyaan tertulis yang digunakan untuk memperoleh informasi dari responden dalam arti laporan tentang pribadinya atau hal-hal yang ia ketahui. Adapun angket yang diberikan terbagi atas dua variabel, yaitu beban kerja dan produktifitas kerja pegawai.

3. Dokumentasi

Dokumentasi adalah suatu cara untuk memperoleh informasi mengenai hal-hal atau variabel yang ada dalam penelitan ini yang berupa catatan, transkrip, buku,surat kabar, majalah, notulen rapat, agenda dan sebagainya. Metode ini digunakan untuk mendapatkan data tentang jumlah pegawai, jenjang pangkat, jam masuk dan jam pulang kerja pegawai pemasaran, dan jenjang pendidikan yang dimiliki. Serta aturan-aturan lainnya yang ditetapkan di Dinas Pengairan Provinsi Aceh.

\section{Peralatan Analisis Data}

Analisis regresi linear berganda digunakan untuk menaksir bagaimana keadaan (naik turunnya) variabel dependen, bila dua atau lebih variabel dependen sebagai faktor predictor dimanipulasi (dinaik turunkan nilainya) (Sugiyono, 2012:277). Bila dijabarkan secara matematis bentuk persamaan dari regresi linier berganda adalah

\begin{tabular}{|c|c|}
\hline & \\
\hline Y & = Motivasi Kerja \\
\hline$\alpha$ & $=$ Konstanta \\
\hline$X_{1}$ & $=$ Penempatan \\
\hline & = Beban Kerja+ \\
\hline $\begin{array}{l}\beta_{1} \operatorname{dan} \beta_{2} \\
e\end{array}$ & $\begin{array}{l}=\text { Koefisien regresi } X_{1} \text { dan } X_{2} \\
=\text { Error term }\end{array}$ \\
\hline
\end{tabular}
sebagai berikut:

\section{Dimana:}

$$
Y=a+\beta_{1} X_{1}+\beta_{2} X_{2}+e
$$

\section{HASIL PENELITIAN DAN PEMBAHASAN}

\section{Hasil Uji Asumsi Klasik \\ Pengujian Normalitas}

Normalitas data merupakah langkah awal yang harus dilakukan untuk setiap analisis multivariat, khususnya jika tujuannya adalah inferensi. Jika terdapat normalitas, maka residual akan terdistribusi secara normal dan independen yaitu perbedaan anatar nilai prediksi dengan skor yang sesungguhnya atau error akan terdistribusi secara simetri disekitar nilai means sama dengan nol. Hasil pengolahan data menghasilkan normal normal probability plot yang memperlihatkan bahwa garis yang menggambarkan data sesungguhnya mengikuti garis diagonal seperti terlihat dalam Gambar dibawah ini : 


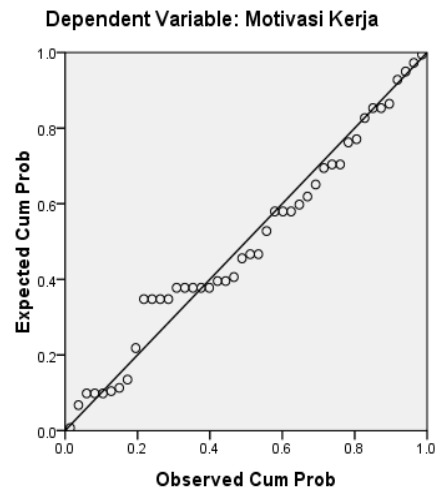

Gambar 2. Normal Probability Plot Hasil Pengujian Normalitas Data

Berdasarkan Gambar diatas menunjukkan bahwa garis yang menggambarkan data sesungguhnya mengikuti garis diagonalnya sehingga dapat diartikan bahwa data yang digunakan dalam penelitian ini terdistribusi secara normal.

\section{Pengujian Multikolinearitas}

Uji multikolinearitas bertujuan untuk menguji apakah model regresi ditemukan adanya korelasi antar variabel bebas (independen). Model regresi yang baik seharusnya tidak terjadi korelasi di antara variabel independen (Ghozali, 2011:105). Untuk mendeteksi ada tidaknya multikolinieritas dapat dilihat pada besaran Variance Inflation Factor (VIF) dan Tolerance. Nilai cutoff yang umum dipakai untuk menunjukkan adanya multikolinearitas adalah nilai tolerance $\leq 0,10$ atau sama dengan nilai VIF $\geq 10$, seperti terlihat dalam Tabel 1 dibawah :

Tabel 1. Hasil Pengujian Multikolinieritas

\begin{tabular}{|c|l|c|c|}
\hline No & \multicolumn{1}{|c|}{ Variabel } & Tolerance & VIF \\
\hline 1 & Penempatan $\left(\mathrm{X}_{1}\right)$ & 0,625 & 1,600 \\
\hline 2 & Beban Kerja $\left(\mathrm{X}_{2}\right)$ & 0,625 & 1,600 \\
\hline
\end{tabular}

Sumber: Data Primer (Diolah), 2019

Berdasarkan Tabel diatas maka dapat dilihat bahwa variabel penempatan dan beban kerja mempunyai nilai tolerance sebesar 0,625 atau $>0,10$ sama dengan nilai VIF sebesar 1,600 atau $<10$, maka tidak terjadi gejala multikolinieritas.

\section{Pengujian Heteroskedastisitas}

Uji heteroskedastisitas bertujuan menguji apakah dalam model regresi terjadi ketidaksamaan variance dari residual satu pengamatan kepengamatan yang lain. Jika variance dari residual satu pengamatan kepengamatan yang lain tetap, maka disebut homoskedastisitas dan jika berbeda disebut heteroskedastisitas. Hasil pengolahan data menunjukkan grafik scatterplot seperti terlihat pada Gambar dibawah.

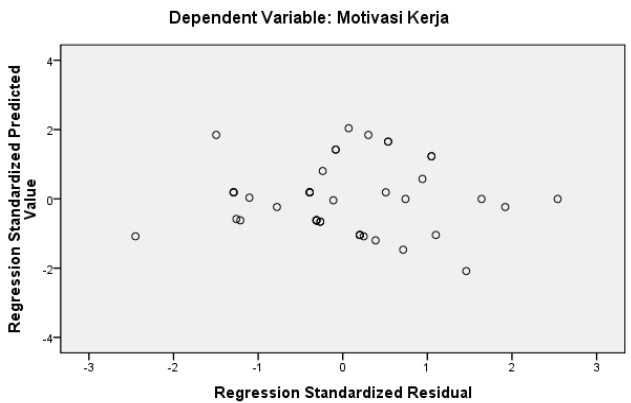

Gambar 3. Grafik Scatterplot Hasil Pengujian Heteroskesdastisitas 
Berdasarkan Gambar 3 memperlihatkan bahwa grafik scatterplot tidak memiliki pola tertentu, dan titik-titik menyebar diatas dan dibawah angka 0 pada sumbu Y, maka dapat diartikan tidak terjadi gejala heteroskedastisitas.

\section{PEMBAHASAN}

\section{Koefisien Korelasi dan Determinasi}

Untuk melihat hubungan dan pengaruh dari variabel penempatan dan beban kerja terhadap motivasi kerja pegawai pada Kantor Kantor Dinas Pengairan Provinsi Aceh berdasarkan korelasi dan determinasi dapat dilihat pada Tabel dibawah :

Tabel 2. Nilai Koefisien Korelasi (R) dan Nilai Koefisien Determinasi $\left(\mathrm{R}^{2}\right)$

Model Summary ${ }^{b}$

\begin{tabular}{|c|c|c|c|c|c|c|c|c|c|c|}
\hline \multirow[b]{2}{*}{ Model } & \multirow[b]{2}{*}{$\mathrm{R}$} & \multirow[b]{2}{*}{$\mathrm{RSc}$} & \multirow[b]{2}{*}{$\begin{array}{l}\text { Adjusted R } \\
\text { Square }\end{array}$} & \multirow{2}{*}{$\begin{array}{l}\text { Std. Error } \\
\text { of the } \\
\text { Estimate }\end{array}$} & \multicolumn{5}{|c|}{ Change Statistics } & \multirow[b]{2}{*}{$\begin{array}{l}\text { Durbin- } \\
\text { Watson }\end{array}$} \\
\hline & & & & & $\begin{array}{l}\text { R Square } \\
\text { Change }\end{array}$ & $\begin{array}{c}\mathrm{F} \\
\text { Change }\end{array}$ & df1 $\mid$ & df2 & $\begin{array}{l}\text { Sig. F } \\
\text { Change }\end{array}$ & \\
\hline- & .778 & .606 & .586 & 1.112 & .606 & 31.475 & & 41 & .000 & 2.079 \\
\hline
\end{tabular}

a. Predictors: (Constant), Beban Kerja, Penempatan

b. Dependent Variable: Motivasi Kerja

Sumber: Data Primer (Diolah), 2019.

Berdasarkan Tabel diatas, maka dapat dijelaskan koefisien korelasi dan determinasi sebagai berikut, yaitu:

1. Koefisien korelasi $(\mathrm{R})$ sebesar 0,778 yang menunjukkan bahwa hubungan (korelasi) antara variabel bebas dengan variabel terikat sebesar $77,8 \%$, artinya motivasi kerja pegawai pada Kantor Kantor Dinas Pengairan Provinsi Aceh mempunyai hubungan yang cukup erat dan positif dengan penempatan $\left(X_{1}\right)$ dan beban kerja $\left(\mathrm{X}_{2}\right)$.

2. Korelasi determinasi $\left(R^{2}\right)$ sebesar 0,606 , artinya sebesar $60,6 \%$ perubahan-perubahan dalam variabel terikat yaitu motivasi kerja pegawai dapat dijelaskan oleh perubahan-perubahan dalam penempatan $\left(X_{1}\right)$ dan beban kerja $\left(X_{2}\right)$. Sedangkan selebihnya yaitu sebesar 39,4\% dijelaskan oleh variabel lain diluar dari pada penelitian ini, misalkan penghargaan, kompensasi, budaya organisasi, disiplin kerja dan lain-lain.

\section{Pembuktian Hipotesis \\ Uji F (Simultan)}

Hasil pengujian statistik menunjukkan nilai $F_{\text {hitung }}$ sebesar 31,475 nilai $F_{\text {tabel }}$ pada tingkat keyakinan 95 persen menunjukkan angka sebesar 3,226 . Karena nilai $F_{\text {hitung }}>F_{\text {tabel }}(31,475>3,226)$. Artinya penempatan $\left(X_{1}\right)$ dan beban kerja $\left(\mathrm{X}_{2}\right)$ secara simultan berpengaruh signifikan terhadap motivasi kerja pegawai pada Kantor Kantor Dinas Pengairan Provinsi Aceh, sehingga hipotesis Ha diterima.

\section{Uji t (Parsial)}

Uji $\mathrm{t}$ (parsial) dilakukan untuk mencari pengaruh variabel bebas terhadap variabel terikat dalam persamaan regresi secara parsial dengan mengasumsikan variabel lain dianggap konstan. Uji t dilakukan dengan membandingkan antara nilai thitung dengan nilai $t_{\text {tabel, }}$ yaitu:

1. Hipotesis pertama pada variabel penempatan $\left(X_{1}\right)$ menunjukkan nilai $t_{\text {hitung }}>t_{\text {tabel }}(4,756>2,017)$. Artinya penempatan secara parsial berpengaruh signifikan terhadap motivasi kerja pegawai pada Kantor Kantor Dinas Pengairan Provinsi Aceh, sehingga hipotesis pertama Ha diterima.

2. Hipotesis kedua pada variabel beban kerja $\left(X_{2}\right)$ menunjukkan nilai thitung $>t_{\text {tabel }}(2,109>2,017)$. Artinya beban kerja secara parsial berpengaruh signifikan terhadap motivasi kerja pegawai pada Kantor Kantor Dinas Pengairan Provinsi Aceh, sehingga hipotesis kedua Ha diterima.

Untuk lebih jelasnya mengenai hasil uji $\mathrm{F}$ dan uji t sebagai tolok ukur pengujian hipotesis dapat dilihat Tabel dibawah. 
Tabel 3. Ringkasan Pengujian Hipotesis

\begin{tabular}{|c|c|c|c|}
\hline \multirow{2}{*}{ Bentuk Pengujian } & \multicolumn{2}{|c|}{ Nilai Statistik } & \multirow{2}{*}{ Keterangan } \\
\hline & $F_{\text {hitung }}$ & $\mathrm{F}_{\text {tabel }}$ & \\
\hline Pengujian secara simultan & 31,475 & 3,226 & $\begin{array}{l}\text { Kedua variabel berpengaruh signifikan } \\
\text { (hipotesis Ha diterima). }\end{array}$ \\
\hline Pengujian secara parsial & $t_{\text {hitung }}$ & $t_{\text {tabel }}$ & \\
\hline Penempatan $\left(\mathrm{X}_{1}\right)$ & 4,756 & 2,017 & Kepuasan gaji berpengaruh signifikan \\
\hline Beban Kerja $\left(\mathrm{X}_{2}\right)$ & 2,857 & 2,017 & Beban kerja berpengaruh signifikan \\
\hline
\end{tabular}

Sumber: Data Primer (Diolah), 2016.

Berdasarkan Tabel diatas jelaslah bahwa baik secara simultan maupun secara parsial penempatan dan beban kerja berpengaruh signifikan terhadap motivasi kerja pegawai pada Kantor Dinas Pengairan Provinsi Aceh. Hal ini berarti bahwa penempatan dan beban kerja secara nyata dapat meningkatkan motivasi kerja pegawai pada Kantor Dinas Pengairan Provinsi Aceh

\section{KESIMPULAN DAN SARAN}

Berdasarkan hasil penelitian dan pembahasan maka dapat disimpulkan beberapa hal sebagai berikut:

1. Hasil pengujian statistik uji $F$ menunjukkan bahwa nilai Fhitung $>$ Ftabel $(31,475>3,226)$. Artinya penempatan dan beban kerja secara simultan berpengaruh signifikan terhadap motivasi kerja pegawai pada Kantor Dinas Pengairan Provinsi Aceh.

2. Hasil pengujian uji t menyatakan bahwa nilai thitung $>$ ttabel $(4,756>2,017)$. Artinya penempatan secara parsial berpengaruh signifikan terhadap motivasi kerja pegawai pada Kantor Dinas Pengairan Provinsi Aceh.

3. Hasil pengujian uji t menyatakan bahwa nilai thitung>ttabel $(2,109>2,017)$. Artinya beban kerja secara parsial berpengaruh signifikan terhadap motivasi kerja pegawai pada Kantor Dinas Pengairan Provinsi Aceh.

4. Nilai koefesien korelasi (R) menunjukkan bahwa derajat hubungan (korelasi) antara penempatan dan beban kerja dengan motivasi kerja sebesar $77,8 \%$, artinya motivasi kerja pegawai pada Kantor Dinas Pengairan Provinsi Aceh mempunyai hubungan cukup erat dan positif dengan penempatan dan beban kerja.

5. Nilai koefesien determinasi (R2) menunjukkan bahwa pengaruh penempatan dan beban kerja terhadap motivasi kerja pegawai pada Kantor Dinas Pengairan Provinsi Aceh sebesar 0,606 atau 60,6\%, dan sisanya sebesar $39,4 \%$ dijelaskan oleh variabel lain diluar dari penelitian ini misalnya penghargaan, kompensasi, budaya organisasi, disiplin kerja dan lain-lain

\section{Saran}

Berdasarkan kesimpulan yang diperoleh dari hasil penelitian, beberapa saran yang diusulkan adalah:

1. Pada Kantor Dinas Pengairan Provinsi Aceh

a. Pada Kantor Dinas Pengaiaran Provinsi Aceh diharapkan terus mengembangkan penempatan untuk meningkatkan motivasi kerja pegawai, dilihat dari kuesioner yang telah diisi oleh pegawai Kantor Dinas Pengaiaran Provinsi Aceh diperoleh data bahwa penempaan dapat mempengaruhi motivasi kerja, sehingga dengan adanya penepatan kerja yang maksimal maka motivasi kerja pegawai akan meningkat.

b. Variabel beban kerja merupakan variabel yang paling rendah pengaruhnya terhadap motivasi kerja pegawai pada Kantor Dinas Pengaiaran Provinsi Aceh dibandingkan dengan penempatan. Untuk itu pihak pada Kantor Dinas Pengaiaran Provinsi Aceh hendaknya lebih menekankan pada beban kerja pegawai agar motivasi kerja pegawai dapat meningkat.

2. Pada Penelitian Selanjutnya

a. Penelitian-penelitian yang lebih lanjut hendaknya menambah variabel lain yang dapat mempengaruhi motivasi kerja pegawai, karena dengan semakin baik motivasi kerja pegawai maka akan berpengaruh baik juga bagi Kantor Dinas Pengairan Provinsi Aceh.

b. Penelitian selanjutnya, diharapkan dapat digunakan sebagai salah satu sumber data untuk penelitian selanjutnya dan dilakukan penelitian lebih lanjut berdasarkan faktor lainnya, variabel yang berbeda, jumlah sampel yang lebih banyak dan tempat yang berbeda. 


\section{REFERENSI}

[1] Arikunto, Suharsimi. 2011. Prosedur Penelitian Suatu Pendekatan Praktik. Rineka Cipta: Jakarta.

[2] Devi Sartika, Bambang Swasto dan Heru Susilo. 2008. Pengaruh Budaya Organisasi dan Motivasi Kerja terhadap Kinerja Karyawan Dinas Pekerjaan Umum di Sumatera Selatan, Jurnal Ekonomi dan Bisnis, Volume 6, Nomor 2, ISSN 142-6435. Universitas Brawijaya: Malang.

[3] Dhania Rama, Dhini. 2010. Pengaruh Stres Kerja, Beban Kerja Terhadap Kepuasan Kerja (Studi pada Medical Representatif di Kota Kudus). Jurnal. Universitas Muria Kudus: Kudus.

[4] Frans Farlen. 2011. Pengaruh Motivasi dan Kemampuan Terhadap Kinerja Karyawan (Studi pada Karyawan PT. United Tractors Tbk Samarinda). Skripsi. Universitas VETERAN: Yogyakarta.

[5] Faustino Cardoso. 2008. Manajemen Sumber Daya Manusia. Bumi Aksara: Jakarta.

[6] Ferdinand. 2006. Metode Penelitian Manajemen, Edisi II. Penerbit Universitas Diponegoro: Semarang.

[7] Ghozali, Imam. 2011. Aplikasi Analisis Multivariate Dengan Program SPSS, Penerbit Universitas Diponegoro: Semarang.

[8] George \& Jones. 2009. Pengantar Kebijakan Publik (Public Policy), Diterjemahkan oleh Ricky Istamto, Rajawali Pers: Jakarta.

[9] Made Bagus Githa Wijaya dan I Wayan Suana. 2013. Pengaruh Penempatan Dan Pengalaman Terhadap Kepuasan Dan Kinerja Karyawan Hotel Melia Benoa Pada Bagian food and beverage service. Fakultas Ekonomi Universitas Udayana (Unud), Bali, Indonesia.

[10] Mangkunegara, Anwar Prabu. 2009. Sumber Daya Manusia perusahaan. Remaja. Rosdakarya: Bandung.

[11] Marthis, Robert L. dan Jackson, John H. 2009. Manajemen Sumber Daya Manusia. Salemba Empat: Jakarta.

[12] Nawawi, Hadari. 2007. Manajemen Sumber Daya Manusia Untuk Bisnis yang Kompetitif. Penerbit Gajah Mada University Press: Yogyakarta.

[13] Rival, Veithzal. 2011. Manajemen Sumber Daya Manusia Untuk Perusahaan Dari Teori Ke Praktek. PT. Raja Grafindo: Jakarta.

[14] Robbins, S. P. 2009. Perilaku Organisasi. PT Macanan Jaya Cemerlang: Jakarta.

[15] Saydam Gouzali. 2008. Manajemen Sumber Daya Manusia. Penerbit PT. Toko Gunung Agung: Jakarta.

[16] Sedarmayanti. 2011. Tata Kerja dan Produktivitas Kerja: Suatu Tinjauan Dari Aspek Ergonomi Atau Kaitan Antara Manusia Dengan Lingkungan Kerjanya. Cetakan Ketiga. Mandar Maju: Bandung.

[17] Sekaran, Uma. 2006. Research Methods For Business: Metodologi Penelitian : Untuk Bisnis. Salemba Empat: Jakarta.

[18] Setiaji, Bambang. 2009. Panduan Riset dengan Pendekatan Kuantitatif. Universitas Muhammadiyah: Surakarta.

[19] Siswanto. 2007. Pengantar Manajemen. Penerbit Bumi Aksara: Jakarta.

[20] Sugiyanto. 2009. Model-Model Pembelajaran Inovatif. Panitia Sertifikasi: Surakarta.

[21] Sugiyono. 2012. Metode Penelitian Kuantitatif Kualitatif Dan R\&D. CV. Alfabeta: Bandung.

[22] Suryabrata, Sumadi. 2009. Metodelogi Penelitian. Rajawali Pers: Jakarta.

[23] Supardi, M.d. 2007. Metodelogi Penelitian. Yayasan Cerdas Press: Mataram.

[24] Tarwaka. 2011. Dasar-Dasar Pengetahuan Ergonomi Dan Aplikasi Di Tempat Kerja. Harapan Press Solo: Solo.

[25] Umar, Husein. 2011. Desain Penelitian MSDM dan Perilaku Karyawan, Seri Desain Penelitian Bisnis. PT Rajagrafindo Persada: Jakarta.

[26] Wagner, John dan John R. Hollenbeck. 2009. Organizational Behavior: Securing Competitive Advantage. Routledge: New York.

[27] Winardi. 2011. Motivasi dan Pemotivasian Dalam Manajemen. Cetakan ke 6, Rajawali Pers: Jakarta. 